\title{
By the Hands of Rhea: Notes on the Juridical Meaning of the Bear
}

\author{
Edward Mussawir*
}

\section{Abstract:}

This article follows some tracks of an animal (the bear) in the work of jurisprudence. Starting with the common law of civil liability for keepers of bears, this article explores the significance of the bear in nineteenth century case law and legal philology, showing that the animal itself does not leave the historical contours of legal doctrine unmodified. Reflecting in particular on the work of nineteenth century Swiss jurist and philologist, Johann Jakob Bachofen, the article examines the imprint that the bear leaves in legal literature and the implications to be drawn from the historical attempts to search for an elusive maternal symbolic in jurisprudence. To speak of an animal in its relation to 'right' requires first of all an attention to the distinct shape and the distinct gender this animal has acquired in the thought and discipline of law.

'Don't go in search of the tracks of the bear that's present.'

\section{Besozzi v Harris}

In 1858 a case was heard at the Bristol assizes concerning a woman who had been attacked by a bear on the Island of Steep Holm in the Bristol channel. The case is recorded in Foster and Finlason's Reports of cases decided at nisi prius and at the crown side on circuit: with select decisions at chambers. vol 1., but one can also find it reported in various newspapers of the time which describe the scene - which obviously held some interest to the broader public - in more detail. ${ }^{2}$

The plaintiff Miss Besozzi, a young woman, made an excursion to the island of Steep Holm with a few of her friends. The defendant, Mr Harris was the only resident, along with his family, on the

\footnotetext{
* Lecturer, Griffith Law School, Griffith University. I would like to thank Judith Grbich, Cressida Limon and Yoriko Otomo for the opportunity and the kind invitation to contribute to this edition of the Australian Feminist Law Journal. I would also like to thank the anonymous referees for their generous and helpful comments on the original version of this manuscript. This piece is for mothers that have given birth to and cared for our misshapen ideas.

${ }^{1}$ Hunting proverb (from Proverbs of Zenobius) quoted in Johann Jakob Bachofen, Der Bær in den Religionen des Alterthums (Basel: Ch Meyri, 1863), p 3.

${ }^{2}$ Besozzi v Harris [1858] 1 F \& F 92. For some of the newspaper reports see, London Daily News, April 12, 1858, p 6; Evening Herald, April 12, 1858, p 6; London Standard, April 12, 1858, p 6; Lloyd's Weekly Newspaper, April 18, 1858, p 8. The case was also reported in Queensland Australia in The Moreton Bay Courier, July 10, 1858, p 3.
} 
small island where he farmed the land and occupied a house which he advertised and used as an inn for visitors. When the group reached the island, Besozzi's friends climbed to the top of the Holm while Besozzi and a man named Gully, who she had met on the boat, remained behind at the house for a few minutes while the latter ordered dinner. They were about to leave to join their friends when the defendant's daughter Miss Harris indicated that they should leave the house through a particular door. Outside, they then went up some steps where they found two diverging paths, one going a little to the left and the other a little to the right. Both of the paths were equally worn and there was no direction-sign to indicate that one path should be used any more than the other. The pair followed the left path which, as it happened, passed close to a bear that Harris kept on his property tied to a six foot chain.

The London Daily News records the plaintiff's statement alleging that the bear 'violently and ferociously attacked and seized the plaintiff, squeezed her, and dragged her along the ground: threw her down, and kept her upon the ground for a long space of time, and bit, tore, lacerated, wounded and injured her, whereby she became ill for a long space of time, and was forced to undergo divers painful surgical operations, and endured great pain and anguish of body and mind, and became unable to discharge her duties as a governess. ${ }^{\prime 3}$ As the account goes, Gully did what he could to help the plaintiff while in the grips of the bear, another man came to assist and broke an umbrella over the animal and a third, Mr Hazard used a stick to beat it away, eventually successfully striking it in the eye and making a narrow escape himself. The attack was described as very savage.

The defendant raised a number of arguments to suggest that he should not be held liable for the actions of the bear and the damage it inflicted on the plaintiff. Firstly, it was argued that the bear was tame, and that it had never shown any propensity to do harm in the past. Evidence was admitted, despite the plaintiff's objection, suggesting that Mr Harris had every reason to believe that the bear was harmless. As the Daily News notes: 'He had had it for three years and it had gone about like a dog, playing with the children, running in and out of the house, going about the island with the defendant's men, and behaving in the most playful and docile manner.' ${ }^{4}$ A second argument was made that the animal had been securely chained up on a part of the property that the plaintiff had no right or occasion to go: the path leading only to Mr Harris's fishing-house. A third suggestion was that the plaintiff knew that the bear was there and that she should have known to keep a safe distance. Harris claimed that Besozzi had at the time blamed Mr Gully for taking her so close to the bear and that she wouldn't have gone up close had she not been told that it was blind. Gully did admit to seeing it and that he had heard another man note as they went up the steps that

\footnotetext{
${ }^{3}$ London Daily News, April 12, 1858, p 6.

${ }^{4}$ London Daily News, April 12, 1858, p 6.
} 
it was as blind as a bat. But Besozzi herself denied having seen the bear before she was in its grasp and denied that she had earlier told Mr Harris that she was going to feed it biscuits.

The question was whether Mr Harris, as the keeper of this bear, was liable for the injuries suffered by Besozzi. The action on the case raised an important principle in relation to civil liability for animals in common law. In directing the jury in the case, the judge Crowder J summed up as follows:

The statement in the declaration, that the defendant knew the bear to be of a fierce nature, must be taken to be proved, as every one must know that such animals as lions and bears are of a savage nature. For though such nature may sleep for a time, this case shows that it may wake up at any time. A person who keeps such an animal is bound so to keep it that it shall do no damage. If it be insufficiently kept, or so kept that a person passing is not sufficiently protected, the owner is liable. If the plaintiff, with knowledge that the bear was there, put herself in a position to receive the injury, she could not recover. But, assuming such knowledge, it is for you to say whether she had such notice of the proximity of the bear as would amount to negligence disentitling her to recover. ${ }^{5}$

The jury found for the plaintiff and awarded her the sum of $50 \mathrm{f}$.

\section{The jurisprudential meaning of the bear}

I want to pause for a moment on something of the jurisprudential context for this case. The purpose with which I want to approach it is obviously not purely expository and doctrinal, nor simply as a matter of recounting a certain historical curiosity. The question that I want in some way to elicit, using this case as a cue, is a question that rather concerns the meaning that the bear has in jurisprudence. What, if anything, is the significance of this animal - the bear - as it appears in law and juridical knowledge? An attention to the meaning of the animal, in a field that is too often quick to look for normative abstractions, is not a simple task. An animal is something that finds itself easily alienated in the conceptual language of law. In trying to describe the meaning that an animal has in a juridical sense then, one tends to run the risk of leaving it with only the vaguest relation to the figure it otherwise casts, often more vividly, in our imagination. This bear is soon caught under the shapeless figure that technical categories tend to construct in the world of legal principle.

At the same time however, the task that I have described seems to bring with it also something of the reverse difficulty. To speak about the juridical meaning of the bear is to tread precariously in a

\footnotetext{
${ }^{5}$ Besozzi v Harris [1858] 1 F \& F 92 at 93.
} 
rhetorical field that, revelling in representation and figuration, treats the legal meaning as only a subset of our moral, ethical and literary perceptions and sensibilities. From this perspective, one finds cultural depictions of the bear only too readily, and is tempted to treat these elaborate depictions, whether they enter into legal discourse or not, as though they provide the more meaningful subject of analysis. We cannot of course expect jurisprudence to simply mirror these images that we find in a number of discursive settings: fictional or non-fictional. It is noteworthy for example - although far from surprising - the lengths that are gone to by the parties and some of the other witnesses in Besozzi v Harris ('Besozzi'), from what one can glean from the record, to present the bear in a favourable, if exaggerated light. ${ }^{6}$ But even where these rhetorical representations are accepted as evidence by the court, what they give us is not much more than an appeal to a popular affective conception of the animal fitted awkwardly to the juridical register: here whether the animal has a characteristically 'fierce' or 'tame' nature and thus whether the defendant can be said to have committed any civil wrong. Whatever the institutional setting and however far we take the analysis, there is nothing necessarily jurisprudential in these elastic figurations by which the parties to legal action attempt to describe the nature of the bear that has occasioned some kind of harm. Like the injuries that it has inflicted, the viciousness or tameness of the bear can so easily be manipulated in language to suit the parties' attempts to establish the lawful responsibility of the other.

If however one starts from a different angle and asks instead what meaning this animal acquires, not just in the sometimes hyperbolic discourse that enters the courtroom, but rather in the jurisprudence (the thought of law) itself that attempts to hold as closely as possible to the form in which one makes or defends a claim, then the answers - if one finds them within certain doctrinal limits - cannot afford to be so elastic. One does not craft a specific meaning for the bear in law in the same way one crafts a literary meaning. Even where we say that this juridical craft has an inherently 'fictional' character, 'legal fiction' is not a figurative or metaphorical exercise, but a

\footnotetext{
${ }^{6}$ The following humorous exchange from the court scene recorded in some of the newspaper accounts, attests to something of this embellishment around the meaning and nature of the animal. A witness named Samuel Baker (a farmer) was called upon to testify to the good character of the bear. He said that it was given to his father and 'used to run about the farm, eating with the calves and pigs, and was always gentle. The children used to ride it, and cried when it was given to Mr Harris in exchange for a dog.' After noting that it had been imported from Russia by his brother, counsel for the plaintiff ( $\mathrm{Mr}$ Edlin) seized upon this fact:

'Mr Edlin: Then it was a rugged Russian bear!

Witness (indignantly): No, it was not.

Mr Edlin: Why, you say he came from Russia.

Witness: But he was not a rough 'un. (Laughter.)

The Judge: The learned counsel suggests that he was a ruffian. (Renewed laughter.)

The plaintiff's counsel Mr Prideaux also then observed facetiously that it must have been 'a real gem of a bear' to fit the glowing descriptions provided by the defendant's wife and daughter. London Daily News, April 12, 1858, p 6 .
} 
specific technical device: e.g. to take the false as true in order to construct the right at the level of its procedural form. ${ }^{7}$ What it is that jurisprudence seems to preclude is not a radical liberty taken with the 'truth' in this sense, which it indeed undertakes in the name of right, but a kind of 'figurative ease' that, even as it affords a more elaborate depiction of the animal, brings it no closer to a jurisdiction. ${ }^{8}$ It may be true that in the Besozzi case itself, the descriptions of the bear did not amount to much. According to the direction of the judge, it would make no difference whether the witnesses were describing Harris's individual bear 'Bruin' or simply bears in general. While the defendant is assumed, from the legal point of view, to know what a bear is capable of; the precise meaning of the animal in jurisprudence remains comparatively shrouded, and not only by the meagre outline it assumes on the canvass of positive law. My aim in this paper is to elicit something of the imprint that this animal leaves, not just as a representation, but also as a technical modification in the thought of law.

\section{The bear in the common law of civil liability for animals}

To begin this exploration, it is useful to take a further step back from the case of Besozzi and to focus on the development of the law relating to civil liability for animals more generally in which the case finds its context. The common law regarding liability for animals that inflict injury on individuals evolved ostensibly through the writ and action that came to be known in England as scienter. Modern authors including most notably Glanville Williams and more recently Bernard S. Jackson have written extensively about the origins of this writ as well as the ancient Babylonian, Jewish, Roman laws and teachings etc that preceded it and that may have had some influence on its development. $^{9}$

Williams explains that the English history shows legal actions used to hold individuals accountable for the dangerous behaviour of their animals taking two early forms. One of those was trespass. This

\footnotetext{
${ }^{7}$ See Yan Thomas, 'Fictio legis: L'empire de la Fiction Romaine et ses Limites Médiévales' (1995) 21 Droits 1763.

${ }^{8}$ For the citation and consideration of work that has recently attempted to situate questions of jurisdiction as the primary concern of jurisprudence, see Olivia Barr, 'Walking with Empire' (2013) 38 Australian Feminist Law Journal 59-74, at 62 (n 15).

${ }^{9}$ See Glanville Williams, Liability for Animals: An Account of the Development and Present Law of Tortious Liability for Animals, Distress Damage Feasant and the Duty to Fence, in Great Britain, Northern Ireland and the Common-law Dominions (Cambridge: Cambridge University Press, 1939), pp 278-284; Bernard S Jackson, 'On the Origins of Scienter' (1978) 94 Law Quarterly Review 85-102. Jackson observes that: 'In investigating the origins of the writ, we must distinguish between the source of the principle, the literary ancestry of its terminology, the mode of its introduction into English law, and the reason for its adoption.' Jackson, 'On the Origins of Scienter', p. 85.
} 
form of action only applied where an animal was in some way directly incited by its owner to attack another and which caused damage vi et armis - that is, effectively with 'force and arms' ${ }^{10}$ - the animal being essentially an extension of the individual's intent to unlawfully interfere with property or person. The other shape that it took however - and through which the modern law of scienter was derived - was through the 'action on the case' where the act of the defendant - not necessarily having directly incited his animal to do harm - nevertheless was responsible for having "knowingly kept' an animal that was in the habit of doing harm. This form, traceable to an action used first in a plea roll of 1387, frames the action as 'Quare quendam canem ad mordendum aves consuetum apud A. scienter retinuit...' ('Where A knowingly kept a dog accustomed to biting birds...'). This form was then easily transposable for other animal couplets such as horse - bull, pig - boar etc. and of course also to damage caused by an animal to a human being (e.g. 'Where A knowingly kept a boar accustomed to biting humans...'). The plaintiff could recover damages from the defendant who had knowledge of the injurious propensity of his animal and who nonetheless kept it in a way that failed to prevent it from doing harm to another.

One of the difficulties in the early interpretation of the principle was the extent of the required knowledge. According to the strict reading, the action was brought simply for having "knowingly kept' the animal. Was it enough then to prove simply that the defendant kept the animal (i.e. not unknowingly) and that it was accustomed to bite? Or was it rather necessary in addition to prove knowledge on the part of the keeper of this specific propensity? In the case of Kinnion $v$ Davies (1637), as Williams relates, a declaration was held invalid because of what was seen as an error in the formulation. ${ }^{11}$ Later cases had allowed it nevertheless on the basis of its conventional use and on the basis that 'knowingly' could theoretically refer to all of the foregoing requirements in the writ including the propensity to bite etc. ${ }^{12}$ To speak of 'unknowingly' keeping an animal would be a meaningless defence in comparison to the more pertinent idea that the keeper did not know that the animal had a vicious inclination. The prevalence of this interpretation, as we know from Besozzi, ended up making the bear an exception to the principle - it being enough to have simply kept the bear knowingly, but not enough to have simply kept an otherwise well-behaved dog, pig etc. Williams found scant evidence to suggest that scienter (knowledge) was not a real, rather than fictitious, element of the early action. ${ }^{13}$ The sole support was the weak authority in William Noy's Maxims (1641), where the bear makes a conspicuous appearance under the question 'How far other

\footnotetext{
${ }^{10}$ Williams, Liability for Animals, p 277. The formulation 'force and arms' was often included fictitiously in early trespass actions.

${ }^{11}$ Williams, Liability for Animals, p 280.

${ }^{12}$ Williams, Liability for Animals, p 280.

${ }^{13}$ Williams, Liability for Animals, p 282-284.
} 
men's contracts and misdemeanours bind us'. The author there notes: 'Every man is bound to make recompense for such hurt as his beasts shall do in the corn or grass of his neighbour, though he knew not that they were there; and for his dogs, bears, etc if they hurt the goods or chattels of any other, because he is to govern them.'14

It was Matthew Hale in his Pleas of the Crown who was supposed to have more accurately described the doctrinal status of liability for bears in common law by separating them into a separate category of so-called 'dangerous' animals (ferae naturae) that were not of the usual domestic kind kept by humans. He therefore explains: 'Tho he have no particular notice, that he did any such thing before, yet if it be a beast, that is ferae naturae, as a lion, a bear, a wolf, yea an ape or monkey, if he get loose and do harm to any person, the owner is liable to an action for the damage... ${ }^{15}$ Besozzi $v$ Harris was in fact the first reported case in England in which this principle had the occasion of being applied for any kind of so-called 'dangerous' animal. As we have already seen, in that case, although the bear did not get loose as such, Harris's prior knowledge of its fierce nature was taken as a juridical presumption. This presumption was upheld in the subsequent case of Wyatt $v$ Rosherville Gardens ('Wyatt') ${ }^{16}$ in 1886 which also concerned an attack by a bear. This case involved a bear kept at the Rosherville Pleasure-gardens, a popular attraction in Gravesend, Kent which hosted many visitors from London at the time. ${ }^{17}$ The plaintiff was attacked after going up close to the bars of the cage in a purpose-built bear den to try to feed the animal. He had supposedly mistaken a two-foot high step leading up to the inner gallery of the den, which he claimed was 'well-worn' through use, as indication that the area was open to the public to get closer to the animal. The report states: 'The bear, it appeared, put a paw through and seized the plaintiff's arm, dragged it into the cage, and seized it in his mouth. ${ }^{18}$ The judge, Mr Baron Huddleston reiterated that anyone who chooses to keep a savage animal such as a bear, does so at their own risk. '[I]n this case it mattered not whether the defendants knew or did not know that this bear was savage-they were equally liable and responsible in either case. ${ }^{19}$

On their own, these legal developments reveal only a small part about the juridical meaning of the bear as such. They show the bear for instance as one of a group of animals that, being typically wild,

\footnotetext{
${ }^{14}$ See William Waller Hening (ed), Maxims in Law and Equity, Comprising Noy's Maxims, Francis's Maxims and Branch's Principia Legis et Aequitatis (Richmond: T. W. White, 1824).

${ }^{15}$ Matthew Hale, The History of the Pleas of the Crown, Vol 1 (London: E. Rider, 1800), p 430.

${ }^{16}$ (1886) 2 TLR 282.

${ }^{17}$ The bear-pit at the site of the Rosherville Gardens was dug up by archaeologists in 2012 and was given listed status by English Heritage in January 2014 before being reburied. See Alasdair Gill, BBC News Online, 'Bear pits and biscuits: The sad fate of Britain's bears', 6 September 2014 . Accessed 30 September 2014 at http://www.bbc.com/news/uk-england-28944797

${ }^{18}$ Wyatt v Rosherville Gardens 2 TLR 282 at 282.

${ }^{19}$ Wyatt v Rosherville Gardens 2 TLR 282 at 283.
} 
generally fierce and dangerous and not (or at least no longer) native to Britain, have been treated in common law outside the regular rule of scienter that would require a prior knowledge on the part of the keeper of a previous vicious propensity in the animal for liability to accrue. The juridical picture of the animal emerges with a little more clarity when one takes into consideration the modern fate that the law of scienter has followed in more recent decades. Williams' seminal study Liability for Animals was influential in highlighting the cumbersome, inconsistent and anomalous aspects to the law relating to civil liability for animals as it existed in early $20^{\text {th }}$ century common law, particularly in comparison to the emergence of more generally applicable rules of negligence. The reasons are not hard to see. The modern law of negligence did not exist in the same form at the time the scienter action was being developed, yet its separate development allowed it by the $20^{\text {th }}$ century to cover virtually all situations that would previously have been actionable under the old writ. Perhaps more significantly, it did so without the supposed confusion or complexity that seemed to arise in relation to ascribing a sometimes abstract legal significance to the animal in question. Williams thought that the long legal development of principle was a straightforward progression moving from what he called 'thing-responsibility' to 'personal responsibility', i.e. from a primitive conception in which revenge was exacted against animals and even inanimate objects where they were thought to have caused harm in themselves in which the keeper could be obliged to do no more than surrender the animal - through the practice in which the animal could be bought back at a sort of ransom - toward the more sophisticated conception in which compensation could be related to a more general idea of personal civil accountability, where only some fault of the keeper determines his or her liability to compensate the plaintiff; any 'fault' on the part of the animal itself rendered meaningless. ${ }^{20}$ With this in mind, the author recommended striking the final blow to an area of law that he considered still retained many remnants of an archaic juridical mindset and consigning the law of scienter to the 'limbo of the past'. ${ }^{21}$

In a number of common law jurisdictions the action was indeed abolished altogether, leaving the general law of negligence, nuisance etc and specific legislative regulations to fill the doctrinal picture for liability for animals. ${ }^{22}$ In the United Kingdom, the Animals Act 1971 (UK) struck a somewhat more conservative course that in many respects codified and regularized the existing doctrine but,

\footnotetext{
${ }^{20}$ Williams, Liability for Animals, pp 265-273.

${ }^{21}$ Williams, Liability for Animals, pp 362-3. See also Thomas Cooley, A Treatise on the Law of Torts quoted in John Hall Ingham, The Law of Animals: A Treatise on Property in Animals, Wild and Domestic and the Rights and Liabilities Arising Therefrom (Philadelphia: T \& J W Johnson \& Co, 1900), p 378.

${ }^{22}$ See Animals Act 1977 (NSW) s 7; Civil Liability Act 1936 (SA) s 18 (formerly Wrongs Act 1936 (SA)); Civil Law (Wrongs) Act 2002 (ACT) s 214; Animal Law Reform Act 1989 (NZ) s 4. In Manitoba (Canada) the common law actions have been abolished but replaced with statutory strict liability, see Animal Liability and Consequential Amendments Act S.M. 1998, c. 8, s 4.
} 
as Peter North observes, has 'undoubtedly created new problems of interpretation [especially] relating to liability for dangerous animals'. ${ }^{23}$ It replaced the pre-existing common law in relation to ferae naturae by stating simply that anyone who is a keeper of an animal that belongs to a 'dangerous species' is liable for 'any damage' caused by it. ${ }^{24}$ A dangerous species is defined as a species that is not commonly domesticated in the British Islands and which would normally have such characteristics that would make it likely, unless restrained, to cause 'severe damage', or that any damage it may cause is likely to be severe. ${ }^{25}$ The Act thus at the very least removed ambiguity that may have still existed after Besozzi and Wyatt over whether strict liability was to apply to a bear that was ostensibly 'tame' and/or reasonably restrained, and also to the situation where the animal may have caused a kind of damage that is unrelated to its supposed 'dangerous' nature, such as if a hypothetical bear had not attacked per se but simply brought and stirred up a hive of bees in the vicinity of a susceptible visitor. ${ }^{26}$

What else if anything has changed with respect to the judicial meaning of the bear with these reforms? Regardless of how far we are willing to follow Williams in his modernist spirit, one cannot ignore the simple fact that the animal takes on quite a different status in these various juridical renditions. In jurisdictions in which the general law of negligence has been allowed to supersede the old scienter action for instance, the presence of the animal, its nature, past behaviour and the way it is kept quite obviously still remain important factors in determining whether a defendant may be liable for an attack. What is different is that these elements arise with no more juridical specificity than any other risk or accident that an individual must take steps to guard against in order to fulfil their civil duty in relation to their 'neighbour'. Though very little may have changed substantially from the perspective of a plaintiff or defendant in this regard in terms of the norms that determine liability, a lot has changed nevertheless from the perspective of what place and meaning the animal has in jurisprudence. In scienter, the animal is not the same as it is in negligence, merely one inessential circumstance in a wider act (a neglect of one's civil duties) considered wrongful at law: rather, according to the form in which the claim is made, it is the very element that legally defines the act's wrongfulness. The bear - which under one formulation of the claim it is wrong to have

\footnotetext{
${ }^{23}$ Peter North, Civil Liability for Animals (Oxford: Oxford University Press, 2012), p 14. North notes that the judicial criticism of the legislation has been particularly scathing, descriptions of it ranging from 'inept' to 'obscure'.

${ }^{24}$ Animals Act 1971 (UK) s 2.

${ }^{25}$ Animals Act 1971 (UK) s 6.

${ }^{26}$ See eg. Discussion in Behrens v Bertram Mills Circus Ltd [1957] 2 QB 1, 17-18.
} 
'knowingly kept' - is not the same as the bear that, like anything that can cause some foreseeable harm, informs the abstract duty that civil law imposes on a person to take reasonable care. ${ }^{27}$

The difference is no less significant when one considers the legislative rendition of the law which in the UK at least mirrors that of the pre-existing common law treatment. The Act retains the attention on the nature of the animal which it continues to classify according to its 'dangerousness' and its likelihood of causing 'severe damage'. But what is easily left out of the picture is the change to the animal that attends the shift in juridical form. As a legislative instrument, the Act can only establish the general category: that of 'dangerous animals' into which various species can supposedly be fitted by definition. From this perspective, a bear for the purposes of the Act has no greater or lesser significance than a member of a wide range of species including a viper or a funnel-web spider for instance, presuming each of these could be considered to be likely to cause 'severe' damage. ${ }^{28}$ But while the legislative arrangement takes us from the general category to the particular species that either falls within or outside its parameters, what it excludes is the juridical movement that has taken us rather in something of the opposite direction, that is starting from the otherwise unclassifiable presence of the specific animal (a bear, a lion ... etc.) - to the idea of the dangerous animal (ferae) as an exception to the principle of scienter in common law - to the juridical categorization of any possible animal in terms of its dangerousness.

If these observations reveal nothing else, it is that one should not neglect the changing shape given to the juridical meaning of the animal through reforms that appear to otherwise leave the normative, moral and economic figures and rationalities effectively intact. What the bear is capable of doing in law and to law is not always the same as what the legal text describes it as capable of doing. Left here, the analysis gives us reason at least to be wary of attempts that, for the sake of doctrinal simplicity, abandon the meaning of the bear to a kind of juridical abstraction. In the following section, I want to consider one particular non-juridical work of scholarship with the hope

\footnotetext{
${ }^{27}$ We see both of these formulations together in Besozzi as well as in Wyatt where there were strong suggestions by the defendants in either case that the plaintiffs had negligently brought the harm upon themselves. It is the same inherent viciousness of the animal for instance that on the one hand makes the defendant liable for having kept it (despite believing it to be tame) as that which would make the plaintiff responsible for (unknowingly) having walked directly into its path. The only thing that differs is the juridical form: the bear that for the defendant has a strict doctrinal status in scienter is for the plaintiff merely a contingent factual circumstance.

${ }^{28}$ The Dangerous Wild Animals Act 1976 (UK) also provides a lengthy schedule of animals for which it is an offence to keep without a licence and, as with equivalent laws in most other common law jurisdictions that regulate the keeping of 'dangerous' or 'exotic' animals, includes bears (Ursidae). Peter North notes that it 'would not be unreasonable for a court to have regard to the list of animals under the 1976 Act when addressing the issue of whether a particular species of animal is "dangerous" with the meaning of the Animals Act 1971.' Peter North, Civil Liability for Animals (Oxford: Oxford University Press, 2012), p 39.
} 
that this work will allow the meaning of the bear to emerge perhaps with an even clearer independence and a sharper jurisprudential outline.

\section{Bachofen's The Bear in the Religions of Antiquity}

In 1863 a work by the Swiss jurist and philologist Johann Jakob Bachofen was published with the title Der Bær in den Religionen des Alterthums (The Bear in the Religions of Antiquity). The work set itself the intriguing aim of exploring the meaning of the bear as it revealed itself through the religion, myth and culture of ancient people. Its author Bachofen was an enigmatic scholar: trained in jurisprudence but following an intensely unique path in classical philology and archaeological inquiry, his work was seen by Walter Benjamin as a kind of 'scientific prophesy'. ${ }^{29}$ Whereas in his early scholarly life Bachofen had written primarily on questions of Roman law and history influences that were kindled during the time he had spent as a student of law at the University of Berlin as well as in France and England before he returned to home town of Basel - it was in the chance-encounters of a solitary traveller and as a private scholar that his attention had been drawn to certain mysteries of archaeology and to the symbolism of tombs. ${ }^{30}$ This very rich terrain upon which Bachofen was able to renew his scholarly activity however, was not necessarily a point of complete departure from his interest in the study of jurisprudence. Rather, having been drawn to law primary by philology, what he thought was necessary to do was to place juristic conceptions more profoundly within the quiet assuredness of the ancient thoughts to which they could be traced and in this way, as he said, to communicate 'the sublimely beautiful ideas of the past to an age that is very much in need of regeneration. ${ }^{31}$ About his time spent in England, Bachofen wrote that he was fascinated on the one side by the 'life of the law courts' and on the other by the British Museum 'with its treasures'. 'Might it not be possible to combine the two aspects,' he wondered, 'to cultivate them both, side by side? ${ }^{32}$

\footnotetext{
${ }^{29}$ Benjamin wrote that: 'Scientific prophesies deserve this name when a more or less profound sense of things to come inspires research which, in itself, hardly goes beyond the general concerns of science.' Walter Benjamin, 'Johann Jakob Bachofen' in Selected Writings Vol. 3 1935-1938, Trans. Edmund Jephcott (Cambridge, Mass.: Harvard University Press, 2002), pp 11-24 at p 11.

${ }^{30}$ Johann Jakob Bachofen, 'My Life in Retrospect' in Myth, Religion and Mother Right: Selected Writings of J. J. Bachofen, Trans. Ralph Manheim (Princeton: Princeton University Press, 1967), pp 10-17.

${ }^{31}$ Johann Jakob Bachofen, 'An Essay on Ancient Mortuary Symbolism' in Myth, Religion and Mother Right: Selected Writings of J. J. Bachofen, Trans. Ralph Manheim (Princeton: Princeton University Press, 1967), p 23.

${ }^{32}$ Bachofen, 'My Life in Retrospect', $p$ 7. Elsewhere in this autobiographical sketch, responding to his former teacher Friedrich Carl von Savigny, he confirms: 'Ancient art draws our heart to classical antiquity, and jurisprudence our mind.' (p 10)
} 
Der Bær is a work that begins and ends with the consideration of a certain Roman bronze statuette that was uncovered in 1832 at Muri near Bern, Switzerland. ${ }^{33}$ The statuette, about twenty centimetres high, has two separate figures facing one another. On the one side the figure of a woman, seated and robed, 'graciously holding the fruits of field and tree, barley, plums and apples' as Bachofen described, wearing a small diadem. ${ }^{34}$ On the other side the figure of a bear which stands on all fours, mouth slightly open and, as one author puts it, 'slinks up to its mistress ... and seems to cause her some embarrassment by its affectionate forwardness'. ${ }^{35}$ Just behind the hind legs of the bear is a small tree whose branches appear to twist up and over the arched back of the bear, holding only a few leaves and a blossom. The pedestal on which each of these figures stands has the inscription: DEAE ARTIONI / LICINIA SABINILLA (To the goddess Artio from Licinia Sabinilla). It is a rare artefact, we are told, not just because of its age - dating to the late second century AD but also for the exquisite craftsmanship and for the rarity of the figure of the bear in monuments of this type.

The approach that Bachofen was to bring to reading this artefact is one that was quite unique and which corresponded in many respects to the approach he had taken in some of his earlier work on mortuary symbolism such as 'The Three Mystery Eggs' and 'Ocnus the Rope Plaiter', ${ }^{36}$ where the author attempted to unravel not just the symbolism in the ancient work of art, but to reconstruct the materiality of the symbol in order to more intimately appreciate the ingenuity of its particular use and the modification made to it in the thought of the artist. Bachofen's study in Der Bær is no exception to this distinctive approach. It is not an attempt to reduce the thought of the artist somehow to the system - whether ideological, religious, linguistic or cosmological - that would provide the present-day key to its interpretation. Rather, assuming a profound and creative idea to be expressed in the immediate artefact in which the bear appears so prominently, he traces a kind of loop that takes us from the simple presence of this particular item, down to the deepest resonances of the symbol depicted in ancient thought, and then back again to the immediate work of art with a renewed appreciation for the originality, singularity and inventiveness of its existence. 'No single phenomenon is able to unveil entirely the thought of other times,' he wrote in the introduction to his study. 'In the end, all we can do is take each symbol in isolation. Even if it later descends into a

\footnotetext{
${ }^{33}$ The statuette is held at Bernisches Historical Museum, Bern. The Museum has published a short book devoted to the figure: Annemarie Kaufmann-Heinimann, Dea Artio: Die Bärengöttin von Muri, Römische Bronzestatue aus einem ländlichen Heiligtum (Bern: Bernischen Historischen Museum, 2002). Further depiction and description of this statuette can be found in Miranda Green, Symbol and Image in Celtic Religious Art (London: Routledge, 1992), p 27-28; Tom Sjöblom, 'The Great Mother: The Cult of the Bear in Celtic Traditions' (2006) 3 Studia Celtica Fennica 71-78 at 76-77.

${ }^{34}$ Johann Jakob Bachofen, Der Bær in den Religionen des Alterthums (Basel: Ch Meyri, 1863), p 34.

${ }^{35}$ J. M.C. Toynbee, Animals in Roman Life and Art, (London: Thames and Hudson, 1973), p 99.

${ }^{36}$ See Bachofen, 'An Essay on Ancient Mortuary Symbolism', pp 24-30, 51-65.
} 
mere attribute: originally it stands on its own power and has a definite meaning there. It's in this that it is initially recognized; the cult association with various deity figures can only be analysed secondarily. I've undertaken this study of the bear upon these fundamentals. ${ }^{37}$

Bachofen attempted to understand the meaning of the bear then not by starting with the figurative attributes that would see it worshipped, represented, personified etc., but first of all - as he suggested - in its independence and isolation, i.e. as the animal itself rather than through the qualities that it offers for anthropomorphic representation. Only from that perspective would it be possible to assign a definite meaning to the animal and to assess the way in which it appears and is used as an element of thought. The text of Der Bær goes on to provide an extensive analysis and meticulous catalogue of the appearances of the bear in ancient and classical art, literature, mythology and religion: an exploration as Bachofen described it of 'the inner connection of all individual phenomena of bears, how they confront us in the testimonies and monuments of antiquity, [in order] to determine and so to present how at the same time the unity of the basic idea and the diversity of its expression among various peoples and in various times duly come forth. ${ }^{38}$

Bachofen thought that there was a 'definite meaning' for the bear that was evident in the material he analysed - material ranging from myth, natural science, poetry, archaeology, art, philosophy and that that meaning was motherhood in its ethical and nurturing aspect. The most salient image that Bachofen saw in this material, and one that seemed to recur in ancient works, is that of the mother bear who gives shape and form to its young through licking. The newborn bear - which supposedly at birth barely resembles anything of its adult form - will emerge into its proper state only with the effort of licking: an effort that expresses and symbolizes the mother's care. It was not in the idea of motherhood as the sign of fertility then that Bachofen saw the bear, but rather in the idea of the mother who with infinite care and dedication, nurtures, trains and gives perfect shape to her young. ${ }^{39}$ The quote that Bachofen drew upon from Horapollo, speaking of ancient animal symbolism, provides: 'When they would symbolise a man born deformed at first, but that has afterwards acquired his proper shape, they delineate a pregnant bear, for it brings forth (a mass of) thick and condensed blood, which is afterwards endued with life by being warmed between its thighs, and perfected by being licked with its tongue. ${ }^{40}$ 'If Horapollo seems to limit these thoughts to a youth which is misshapen,' Bachofen added, 'like one with physical birth defects, then he lends

\footnotetext{
${ }^{37}$ Bachofen, Der Bær, p 4. All translations of this text are the authors own.

${ }^{38}$ Bachofen, Der Bær, p 40.

${ }^{39}$ Bachofen, Der Bær, p 8.

${ }^{40}$ Horapollo, Hieraglyphica 2, 83 quoted in Bachofen, Der Bær, p 5.
} 
this motherly love only an even higher meaning. ${ }^{41}$ He drew attention to the same meaning in Aulus Gellius's Attic Nights where Virgil is said to have produced verses in the manner of a bear since, like with the bear who gives birth to formless young which it shapes by licking, the products of his mind were often rude and imperfect in form and he only gave them a definite form by working over them and polishing them. ${ }^{42}$ It was also this particular sense of maternal care that Bachofen suggested would explain Pythagoras's naming she-bears 'the hands of Rhea' according to Porphyry's Life of Pythagoras. The idea of the bear was linked supposedly not just to the creative principle of motherhood in birth but also to the shaping artisanship of nature and the earth. ${ }^{43}$ In this formulation, Bachofen encouraged his reader to imagine not so much that it was the mother that necessarily resembled a bear when she raised her children through some superhuman care and effort, but that it was the bear itself (and its semblance in art) that supposedly expressed a principle of maternal force inherent in both law and nature.

This meaning for the bear then, which Bachofen traced further through the myths of Callisto and Atalanta among others, was not without a juridical significance for the author of this work. The study in Der Bær makes an even greater impression when one reads it today in the context of the work for which he is most known - Das Mutterrecht (Mother Right) published two years previously in 1861 - a work in which Bachofen had attempted to uncover the evidence for an early maternal juridical symbolic in the art and literature of classical antiquity. According to the thesis of this work, in the early stages of all ancient societies, lawful relations were sustained predominantly through the mother rather than the father, since the maternal relation was in these cultural stages known more immediately than that of the paternal. The traces of this form of juridical thought were left like

\footnotetext{
${ }^{41}$ Bachofen, Der Bær, p 5.

42 Bachofen, Der Bær, p 6.

${ }^{43}$ Bachofen, Der Bær, p 7. 'As with the hand like with the licking bear, the coincidence is all the greater because it is linked not only to the general idea of birth but especially to that artistic perfection, that with which she lends all the products of the Earth, plants, animals, humans her wonderful beauty, and is also distinctly present in Rhea's fingers, the Idaean dactyli and digiti.' In Greek mythology, it is the hands of Rhea that, as the expression of motherly devotion, supposedly both hides her infant child Zeus in a cave on Mount Ida as well as with which she presents his father Cronos with a stone wrapped in swaddling cloth which he duly swallows instead of his own son. The Idaean Dactyloi ('fingers') which Bachofen mentions, were supposed to have arisen from the nymph Anchiale when she grasps the earth with her hands in the Dictaen cave, but are intimately linked with Rhea through having an autochthonous generation and as being invoked along with Rhea on the 'Mount of Bears' where the Argonauts made tribute to the mother of gods so that she would allow them safe conditions to set sail. (Apollonius, Argonautica, 1, 1103-1153). See also Christopher B. Polt, 'The Origin of the Idaean Dactyls (Apollonius Argonautica 1.1129-1131)' (2013) 108(4) Classical Philology 339346. Oppian in Cynegetica, Book 3 (Loeb Classical Library, 1928), pp 125-8 further says that bears have 'hands like human hands' and that the she-bear has such a lust for mating that she 'brings forth her children half formed and not articulate, shapeless flesh, and unjointed and mysterious to behold. At one and the same time she attends to mating and the rearing of her young ... And she licks with her tongue her dear offspring, even as cattle lick one another ... So doth the she bear shape her children by licking; while they whine and mumble incontinently.'
} 
vestiges in the monuments of antiquity and even in patriarchal juridical systems such as Roman law. Thus he invoked from the Roman jurist Paulus the formula according to which: 'The father is always a juridical fiction, the mother a physical fact. ${ }^{44}$ For Bachofen, mother-right was the juridical expression of a culture corresponding to the rise of agriculture and regulated marriage, but prior to its suppression under a paternal power interested only in the management and inheritance of property and patrimony. It was retained in Roman law, he thought, not just in the above formulation, but also as the principle that the soil was to predominate over the seed in terms of the ownership of produce and in the rule that a slave - being outside the patriarchal civil law - was to take her status from the mother, leaving the status of the father as inconsequential. ${ }^{45} \mathrm{Der} B æ r$ rehearses many of these same allusions to an age of maternal right, of which the ancient bear-cults seemed to express for the thinker a primary ethical aspect: the principle by which the first extension of love beyond the limits of the ego to another creature occurs through the mother.

More importantly perhaps, and despite all of the common allusions to the exaltation of motherhood that recur in these two texts, Der Bær seems to find a much more grounded path along which to trace this idea. There is no longer any grand thesis in Der Bær as there was in Das Mutterrecht. There is no attempt, as he said in the latter, at arriving at 'increasingly universal principles' ${ }^{46}$; rather just a small statuette and the animal, the bear that, in its isolation, looks up at us from a distant age. Bachofen returned to the statuette, and armed with the multitude of clues that he had traced for the bear in the cultural and archaeological sources, allowed the reader to glimpse just a little more intimately the force of intimation and the solitary profoundness of thought belonging to the piece of artistry. Here, the anthropomorphic figurations of the bear seemed to fall away in favour of the more isolated meaning he recognized it acquiring in the thought of the one making the dedication. With this in mind, Bachofen suggested, the 'name Artio and the independent animal-form seems sufficient to explain the proper context to every beholder without further help. ${ }^{47}$ It's in this way that in Der Bær, the thought which in Das Mutterrecht could only be presented in an abstract thesis, with all the dangers of the kind of essentialism that the contemporary reception of this work is justifiably wary of ${ }^{48}$ with the help of the bear finds a somewhat more honest expression. What the

\footnotetext{
${ }^{44}$ Bachofen, 'Mother Right' in in Myth, Religion and Mother Right: Selected Writings of J. J. Bachofen, Trans. Ralph Manheim (Princeton: Princeton University Press, 1967), p 133.

${ }^{45}$ Bachofen, 'Mother Right', p 132.

${ }^{46}$ Bachofen, 'Mother Right', p 76.

${ }^{47}$ Bachofen, Der Bær, p 38.

${ }^{48}$ See eg. Nicole Loraux, Born of the Earth: Myth and Politics in Athens, Trans. Selina Stewart (Ithaca: Cornell University Press, 2000), chapters 7-9. Loraux argues that Bachofen in Das Mutterrecht starts what a number of other modern scholars are guilty of: repeating a fragment of Plato's Menexenus as if it were an original or selfevident truth removed, as Loraux puts it, from its 'Platonic jurisdiction'. The fragment, which Bachofen cites in
} 
author said too assuredly of mother right and the juridical meaning of motherhood in the former text, he could say with a renewed simplicity and circumspection in the latter. And it was perhaps above all the contours of the animal - the bear - that afforded the thinker something of this graceful manoeuvre.

\section{Shaw v McCreary}

An overly zealous attempt to 'apply' Bachofen's study to our analysis of the juridical literature on civil liability for bears may yield some unwarranted results. It would be somewhat impetuous for example to try to read the bear in Besozzi as the sign of a motherhood which, lost to the judicial reasoning, returns under the figure of the animal in a kind of allegorical arc. Bachofen's study allows us to see how the bear, not just as a figure or in a certain play of signification, but in its very independence as an animal, can be situated in the construction of a thought with a more or less precise and a more or less profound meaning. The method of arriving at this meaning was for the author as much an individual encounter than a concerted philological and jurisprudential inquiry. But it would be to take the implication of this work too far to allow the meaning ascribed to the animal to become a token allowing us to bypass the sometimes sober doctrinal terrain on which the thought of law is embedded. While it is true that the presence of the bear, through the wounds with which it marks the sphere of civil relation, makes an important difference to the juridical formulation of liability, this difference is not something we can easily confine to a subjective level. What requires our elucidation is not the bear as it exists in the thought of the judge, as though in the thought of an artist, but rather as it exists in the thought of law itself: the jurisprudence whose creativity is exercised only on the heavy weight of legal principle. ${ }^{49}$

Allow me to return then to a third case from our repertoire of $19^{\text {th }}$ century common law scienter jurisprudence concerning bears which we may be able to approach with a renewed interest. In the 1890 Canadian case of Shaw v McCreary ('Shaw'), a bear belonging to one of the defendants John McCreary escaped from a property owned by the second defendant, his wife Mary McCreary, and attacked and injured the plaintiff John Shaw (an infant) on a public street. The bear had supposedly been brought to the property by the husband and kept there where they resided without objection from his wife, who by virtue of the Ontario Statute R. S. O. Ch. 132, sections 3 and 14 owned the

Das Mutterrecht from the French jurist Jacques Cujas quoting Plato is: 'It is not the earth which imitates women, but women who imitate the earth.'

${ }^{49}$ It was this that gave Bachofen an assuredness in the study of myth. 'Product of a cultural period in which life had not yet broken away from the harmony of nature,' he explained, '[myth] shares with nature that unconscious lawfulness which is always lacking in the works of free reflection.' Bachofen, 'Mother Right', p 76. 
property outright with full rights as a single individual or 'femme sole'. The trial judge had found that while an owner of property would normally be held liable for a ferocious animal (ferae naturae) that was kept on that premises, in this case the plaintiff was able to recover damages only from the husband who, the judge thought, was the sole person responsible for the animal and not the wife. ${ }^{50}$ The action against the wife was excluded on the basis that as a wife, she could not have been legally expected to object to her husband's wish to keep the bear on the property. This decision was then overturned on appeal to the Chancery Divisional Court which held that, as the owner of the property which according to the statute she 'might have, hold and enjoy free from her husband's control as if she were sole and unmarried', she was therefore also liable for the harm inflicted by the bear. ${ }^{51}$ Since legally she could have had the animal removed, and the statute said that she held the property as if she were unmarried, the Divisional Court held that the trial judge had erred in excluding her from liability.

There are two points about the meaning of the bear in this case that may shed some light on the jurisprudential situation. The first - to leave the obviously gendered question until later - is in relation to the legal principle concerning the 'escaping bear'. In the two common law cases that had gone before (Besozzi and Wyatt) the bear had made its attack while remaining confined on the defendants property: in Besozzi chained up, in Wyatt confined to a cage. However in Shaw, the bear had escaped this property and made its attack on the street. Each of the judges in the Divisional Court upheld the scienter exception that damage caused by a wild animal such as a bear will bring liability for its keeper regardless of the latter's knowledge of its disposition. However the question of whether, by escaping from either the property of the wife or the possession and captivity of the husband, the animal could still be considered to be 'kept' as such or whether by doing so it had immediately regained its natural state of wildness and belonged to no-one, was not directly addressed. Boyd $\mathrm{C}$ seemed to answer the question with reference to the principle in Rylands $v$ Fletcher, a case which involved not an animal but water escaping from a reservoir. ${ }^{52}$ By allowing a substance onto her property that if it had escaped from the property would be likely to cause

\footnotetext{
${ }^{50}$ Shaw v McCreary [1890] 19 Ontario Reports 39.

${ }^{51}$ Shaw v McCreary [1890] 19 Ontario Reports 39, at 45.

${ }^{52}$ Rylands v Fletcher [1868] UKHL 1. The House of Lords, in upholding the decision of the Court of Exchequer Chamber in this case, had in fact reasoned in the opposite direction: going from the existence of strict liability for animals as one example of a number of areas of tort law recognising liability without a specific negligent act on the part of the defendant, to a broader principle which would by analogy cover this defendant's 'nonnatural' use of water on their property. Williams notes that principle that the mere escape of an animal does not put an end to liability could be since as established since Hale's time and was affirmed in the case of May $v$ Burdett (1846) 9 QB 101 which involved a monkey. Williams, Liability for Animals, p 336.
} 
damage, the owner was according to this principle supposed to be held strictly liable. ${ }^{53}$ As for the bear itself however, we can compare another, much older juridical approach in which it seems to come more distinctly to mind in the shaping of legal principle on the 'escaping' animal. Bernard Jackson for instance draws our attention to an example from the Roman law of pauperies that helps reveal what may be at stake for the bear in a different set of shifting juridical registers. The Roman action for pauperies, which originated from the Twelve Tables (451 BCE), and was in many respects an ancient equivalent to the English scienter writ, provided for remedy to be available to a person who had suffered harm caused by a four-footed animal through no specific legal fault of the defendant. $^{54}$ The remedies provided for by this action involved not just damages but also 'noxal surrender', i.e. handing over the animal itself, as a substitute for pecuniary reparation. Jackson figured that the action at least by the time that the classical jurist Ulpian was writing about it included 'four-footed' wild animals such as bears, notwithstanding the common ambiguity surrounding whether a bear can be said to stand on primarily four or on two feet. But since wild animals could not be owned as such, the Roman jurist provided the following clarification of the scope of the action using the example of an escaping bear: 'if a bear breaks loose and so causes harm, its former owner cannot be sued because he ceased to be owner as soon as the wild animal escaped. Accordingly, if I kill the bear, the corpse is mine. ${ }^{.55}$

When this passage came down to the compilers of Justinian's Digest however, whose task it was to reduce the mass of classical Roman jurisprudence to an enforceable code, they extrapolated from this bear a categorical exception for the pauperies action for all 'beasts wild by nature', leaving the example's more salient point - the fact of its 'breaking loose' - remaining in the text as an awkwardly uninstructive remnant. ${ }^{56}$ Because of this, despite the intimation to the law regarding the ability to maintain property in wild animals, ${ }^{57}$ we do not know for sure the precise meaning for the bear that Ulpian had intended in this passage. Jackson notes: 'It is quite possible ... that the problem of pauperian liability for Ulpian's escaping bear was posed for primarily academic reasons, ${ }^{, 58}$ the

\footnotetext{
${ }^{53}$ Williams admits on this point that dangerous animals 'come indifferently within Rylands $v$ Fletcher and scienter' but that liability under each may be 'in distinct persons', i.e. the owner and the keeper. Williams, Liability for Animals, p 358.

${ }^{54}$ See Digest 9.1.1.

${ }^{55}$ Digest, 9.1.1. Common law mirrors the Roman conception of property in this respect in so far as it divides animals into those of an inherently 'domestic' character and those of an inherently 'wild' character; the former being the subject of ownership while the latter only of possession. Thus to lose possession over a wild animal is therefore to lose any legal right one may have over the thing. Consider however Reg $v$ Gallears 3 New Sess Cas 704 quoted in Ingham, The Law of Animals, p 5, in which it is added that 'the mere circumstance of cutting the animal up makes it property'.

${ }^{56}$ Digest 9.1.1.

${ }^{57}$ See Institutes 2.1.12.

${ }^{58}$ Bernard S. Jackson, 'Liability for Animals in Roman Law' (1978) 37(1) Cambridge Law Journal 122-133, at 136.
} 
action not being a suitable vehicle in any case for liability for wild or dangerous animals in the normal situation. Regardless of this, the Justinian blanket exclusion of all 'beasts wild by nature' nevertheless created an obvious doctrinal anomaly regarding damage caused by such animals: through what action could a keeper of such an animal be held to account if not here? Thus, in relation to the separate area of law governed by the Edict of the Aedile which did prohibit persons from keeping a member of a discrete list of dangerous animals (including a dog, boar, bear and lion) near a highway the contravention of which would allow recovery of damages by an injured party, ${ }^{59}$ the compilers there artfully patched into the Digest the words: 'and generally any dangerous animal' to address the original lacuna. In this way, they brought a class of animals that would otherwise have been inexplicably excluded from liability in one area, back in through a different avenue.

Whether this jurisprudential sequence would have been helpful to acknowledge in Shaw is beside the point. What is noticeable in both the situations is that the bear that we can presume to have appeared with a more isolated and instructive meaning in the classical jurisprudential literature, ended up with the move toward codification being transposed and obfuscated under a more general, less distinctive figure. And it is this that we also observe in Shaw when, rather than being the occasion for a jurisprudential clarification of the principle of the escaping animal as it must have been for Ulpian, whether onto streets or neighbouring land, the bear instead loses its juridical shape by seeming to need to be brought under a more amorphous analogy.

The second problem is somewhat more conspicuous. What, if anything, can we make of the obvious issue of gender in Shaw with respect to the bear? Immediately observable of course particularly on the part of the trial judge in the case is the evidence for a barely-concealed chauvinism of the time, one still holding both to a technically outdated legal situation where a woman's rights were not always considered separate from her husband's as well as to a misogynistic social prejudice which inaccurately assumed the wife to be subject one-sidedly to the wishes of her husband. Much could be said no doubt by bringing the social and historical contexts more clearly into focus. However, from the jurisprudential point of view, it would not be enough just to reveal the chauvinism that persists in the judgment or in the historical register more broadly. What the case reveals about the doctrinal connection that ties the presence of the bear to a certain gendered configuration of law is much more than just what appears as the prejudice of a lower court Canadian judge of the 1890s. More specifically, from the point of view of the meaning of the bear and the law of civil liability, we see in this case again a momentary reversion to an older symbolic: one which places the matrimonial relation ahead of the patrimonial, the law of marital co-habitation ahead of the law of property and

${ }^{59}$ Digest 21.1.39 
civil co-existence. It's as if, under the sign of the bear, the matrimonial bond is able to overwrite every other legal relation, so that whatever obligation the wife might otherwise have owed to third parties at risk of being injured by the bear, if the animal was brought to the property under the auspices of the marriage itself, she cannot be liable. If it is not in other words because the married woman is incapable of holding and managing property separate from her husband that she would (as wife) be excluded from the burden of paying reparation for the injuries inflicted by the bear, it can only be because the abstract rights of ownership are held momentarily beneath this immediate matrimonial protocol: a protocol in which the bear itself appears as more than just any chattel (or substance) held on the property, but under the form of a solemn spousal gift that - even in the face of potential demands from outsiders - cannot lawfully be rejected. ${ }^{60}$ On this basis, the trial judge could refuse to found liability for the bear on the positive legal fiction constructed by the statute i.e. that the defendant held the property 'as if' she were unmarried - in favour of recognizing a matrimonial state of affairs under which this animal could alone be lawfully held or received etc.

The Divisional Court, as we have seen, overturns this juridical aberration and reverts to the 'patrimonial' logic under which ownership of the land carries an authority and control tantamount in this case to 'keeping' the animal. 'The property on which the bear was kept was the separate estate of the defendant Mary McCreary,' Boyd C noted, 'and she had the power to consent to its being harboured there or to have it removed. ${ }^{61}$ The defendant, having 'all the rights of a stranger ... as

\footnotetext{
${ }^{60}$ See for eg. Bachofen's discussion of Polyphemus's courting of Galatea with the offer of a set of bear- cubs as gift, which he considers the remnant of an ancient customary form of bride-price. Bachofen, Der Bær, pp 8-9. See Ovid, Metamorphoses 13, 834: 'I came upon twin cubs of a shaggy bear that you can play with: so alike you can hardly separate them. I came upon them and I said: I shall keep these for my mistress.' Consider also the custom of the Nivhk and Ainu peoples which involve raising young bears by women in a household setting, including suckling bear-cubs. Marjorie Mandelstam Balzer relates that for the Amur in particular, the festival involved live bears being 'raised, preferably as captured cubs sucking human women's milk, kept in cages, and then ritually killed.' Marjorie Mandelstam Balzer, 'Sacred Genders in Siberia: Shamans, Bear Festivals, and Androgyny' in Sabrina Petra Ramet (ed), Gender Reversals and Gender Cultures: Anthropological and Historical Perspectives (London: Routledge, 1996), pp 164-183 at p 172. Lydia Black also explains that the bear used in the festival had to be raised by the clan of 'wife-givers' (as hosts) and killed by a member of the clan of 'wifetakers' (who were the guests). The bear also had to be led around the settlement and into the various dwelling-places and was teased along the way. A wound received from the bear was, according to Black, 'a mark of honor, a sort of laying on of hands in reverse.' Lydia Black, 'The Nivhk (Gilyak) of Sakhalin and the Lower Amur' (1973) 10(1) Arctic Anthropology 1-110, at 95. For the Ainu tradition, Kindaichi and Yoshida explain the belief behind the ritual killing of the bear in the following terms: 'Hitherto, this ceremony has usually been understood by the Japanese to mean that the Ainu kills the bear in order to worship the god of heaven... In Ainu belief, there is no god greater than the bear, therefore it is impossible to suppose that they offer it as a sacrifice to a greater god. Killing a bear is a sacred act, by which they let him return to his home as a god: it is really an act for which the bear should be thankful. The Ainu has no idea of apologizing to a bear which is killed. It is the same idea as treating a guest.' Kyōsuke Kindaichi and Minori Yoshida, 'The Concepts behind the Ainu Bear Festival (Kumamatsuri)' (1949) 5(4) Southwestern Journal of Anthropology 345 at 349350 .

${ }^{61}$ Shaw v McCreary [1890] 19 Ontario Reports 39 at 43.
} 
against her husband', ${ }^{62}$ by accepting the presence of the animal becomes in the Court's view a 'keeper' who, like the husband, is strictly liable. The judges thus accepted in this way the submission of the appellant that, contrary to the position of the trial judge, ' $[t]$ he fact of their living together can make no difference ${ }^{63}$ to her legal responsibilities for the bear.

This reversion, interestingly enough, is then taken a step further by the author of a critique published in the Canada Law Journal the same year. ${ }^{64}$ The author of this piece argues against the decision reached in the Divisional Court as too closely tying the idea of ownership to that of 'keeping' the bear. Thus, under this conception, it is the property-owner's abstract subjective freedom at law that means that - the marriage being strictly irrelevant - she cannot be liable simply for having accepted the animal onto her land. 'The relationship of husband and wife would formerly have protected her from all liability,' this author notes, 'and it certainly does not now, even under the altered state of the law as to the wife's capacity to hold property, impose on the wife any greater liability than if she were a stranger to her husband... This is an effect of the Married Women's Property Act which was hardly contemplated. ${ }^{65}$ Thus, by distancing the bear from a property that the Divisional Court apparently was still imagining as a kind of household necessarily managed by the owner, this commentator analogises that an inn-keeper (as owner) cannot be liable for taking in a 'strolling tramp and his dancing bear' if the bear causes injury on the premises or if it escapes and causes havoc on the street. ${ }^{66}$ In this way, he or she effectively suggested displacing any remaining remnant of the matrimonial significance of the animal - the bear for example being taken as the sign of a happy marital home - still persisting in the logic of the Divisional Court. ${ }^{67}$

\section{'Playing the bear': the gender of reparation}

The wounds inflicted in the case of Shaw, as in Besozzi, appear under the filter of a juridical mentality attuned more to the world of abstract principle than to the symbolic centrality of a particular animal. It is worth mentioning one further historical phenomenon here which - if nothing else - may add something to the picture and which invites speculation concerning the connection of

\footnotetext{
62 Shaw v McCreary [1890] 19 Ontario Reports 39 at 43.

${ }^{63}$ Shaw v McCreary [1890] 19 Ontario Reports 39, at 41.

${ }^{64}$ Anonymous, 'Liability for Injuries by Mischievous Animals' (1890) 26 Canada Law Journal 421-425.

${ }^{65}$ Anonymous, 'Liability for Injuries by Mischievous Animals' (1890) 26 Canada Law Journal 421-425, at 422.

${ }^{66}$ Anonymous, 'Liability for Injuries by Mischievous Animals' (1890) 26 Canada Law Journal 421-425, at 422.

${ }^{67}$ The goes as far as to replace the Divisional Court's analogy of the bear to water in Rylands with an analogy to a gun. The author rhetorically asks: 'If she is liable for the bear going off without leave, owing to her husband's negligence, why should she not be equally liable for his gun going off too, through his negligence?' Anonymous, 'Liability for Injuries by Mischievous Animals' (1890) 26 Canada Law Journal 421-425, at 425.
} 
the bear to the configurations of gender, matrimony and reparation: a phenomenon in which Bachofen himself thought that he recognized 'the oldest system of family law ... in its cultic legal basis $^{68}$ and which has in more recent times captivated a number of scholars of ancient Athens. ${ }^{69}$ Why was it, these scholars have asked, that before they could be married, the girls of Athens were supposedly required to 'play the bear' for the goddess Artemis? In Aristophanes' Old Comedy the Lysistrata (411 BCE), the chorus of aristocratic Athenian women sing a verse that makes mention of being involved in a rite known as the arkteia, where young girls called arktoi (bears) had 'played' or 'imitated' the bear for Artemis at Brauron, by donning or casting down the krokoton (saffron robe). ${ }^{70}$ The mention of this ritual appears in the context of recounting a list of social or religious duties in a woman's life in Athens the precise meaning of which is shrouded in some mystery. ${ }^{71}$ For the scene of the arkteia itself however and in what sense this mysterious rite involved 'playing the bear', scholars have had to rely on certain supplementary sources. On the one side, archaeological discoveries including what are known as krateriskoi, black figure vases recovered from the sanctuary of Brauron, which depict scenes of women of various ages engaged in running races and dancing, either clothed or nude. ${ }^{72}$ There are also fragments of a red-figure vase which show Artemis, Leto and Apollo and two human figures that are either wearing bear-masks or in some stage of beartransformation, and another showing naked girls holding wreaths running away from a bear

\footnotetext{
${ }^{68}$ Bachofen, Der Bær, p 26. For Bachofen's analysis of the phenomenon see pp 24-28.

${ }^{69}$ The extent of the contemporary literature is too vast to list here. For a section of the available material, see the sources listed in the following footnotes.

${ }^{70}$ See Gloria Ferrari, Figures of Speech: Men and Maidens in Ancient Greece (Chicago: University of Chicago Press, 2002), p 166. Ferrari renders the passage from Lysistrata (lines 641-647) as follows:

'When I was seven I promptly served as arrephoros

Then at ten I was corn grinder for the leader;

Then pouring down the saffron mantle (krokoton) I was bear (arktos) at the Brauronia,

And when I was a fair maiden I was basket carrier

Wearing a necklace of dried figs.'

${ }^{71}$ Ferrari indicates that in its context the passage from Aristophanes is meant to be funny, even if we don't know exactly why it is meant to be and she points to the analysis of Pierre Vidal-Naquet who suggests a rhetorical and satirical association to the formal initiation rites that graduate an Athenian male to citizenship. The chorus in Lysistrata accordingly may be 'arguing as if the women of Athens were in fact the citizens. The stages referred to ... those of a fictitious cycle.' Vidal-Naquet quoted in Ferrari, Figures of Speech, p 295 (n 25). ${ }^{72}$ See especially Inge Nielsen, 'The Sanctuary of Artemis Brauronia: Can Architecture and Iconography Help to Locate the Settings of the Rituals' in Tobias Fischer-Hansen and Birte Poulsen (eds) From Artemis to Diana: The Goddess of Man and Beast (Copenhagen: Museum Tusculanum Press, 2009), pp 87-100; Richard Hamilton, 'Alkman and the Athenian Arkteia' (1989) 58(4) Hesperia: The Journal of the American School of Classical Studies at Athens 449-472; Claude Calame, 'Identities of Gods and Heros: Athenian Garden Sanctuaries and Gendered Rites of Passage' in Jan N. Bremmer, Andrew Erskine, Christoph Auffarth, Gods of Ancient Greece: Identities and Transformations (Edinburgh: Edinburgh University Press, 2010), pp. 245-270 at pp 259-263. The common assumption that these vases depicted scenes of the actual ceremony has been called into question by Ferrari who suggests that the nude girls are more likely a representation by $5^{\text {th }}$ century Athenians of an older time at which the incident that instituted the arkteia took place. See Ferrari, Figures of Speech, p 175.
} 
standing on a rock. ${ }^{73}$ On the other side literary sources such as the Byzantine encyclopaedia the Suda and the scholia to the various manuscripts of the Lysistrata which give accounts of the foundation myths supposedly underlying the arkteia and recounting the fact that the ritual had to be performed at some time for girls between the ages of 5 and $10 .^{74}$

Jean-Pierre Vernant and Francoise Frontisi-Ducroux recount a version of the foundation myth of the rite in attempting to describe the significance of the mask in the cults associated with Artemis in ancient Greece, emphasising the role that the goddess played in managing the transitions that males and females had to negotiate and master in their lives: transitions between the states of wildness and tameness, excess and control; the frontier zones that were necessary to navigate in order to cultivate a relation to gendered civic life:

The little girls of Athena could not be married - that is, live with a man - unless, between the ages of five and ten, they had acted out the part of a bear. The miming of a bear did not indicate a return to the wild, as in the case of Callisto who was changed into a bear as a punishment for having failed to remain faithful to the virginal world of the goddess [Artemis] and, through an act of violence, for having known sexual union and childbirth. In the case of the little Athenian girls, it was a matter of reliving the part of a she-bear who, in times past, came to live, tame, among human beings, growing up in their company, in the sanctuary of Artemis. One little girl was naughty or cheeky - certainly imprudent - enough to tease the animal excessively: She got her face scratched, and her brother, in a rage, killed the bear. Ever since, by way of reparation, the daughters of the citizens of Athens had imitated the bear, gradually becoming tame, as she had, overcoming their latent wildness so that they could eventually go and live with a husband, without danger to either partner. ${ }^{75}$

\footnotetext{
${ }^{73}$ Ferrari argues that the scene represents the myth of Callisto where Callisto is turned into a bear for having known sexual relation with Zeus, but just as her son Arcas is about to kill the animal (his mother) the two are turned into the constellations Ursa major and minor. This reading she suggests explains why a ring-dance can constitute 'playing the bear', as what is imitated is not the animal but the constellation. See Ferrari, Figures of Speech, pp 172-174. Bachofen's analysis seems to confirm aspects of this approach, suggesting that the blindness that the bear inflicts on the girl in the temple myth is linked to sexual impurity and explains the wearing of the light-coloured robe on this basis, it being an insignia of having received the consecration. Bachofen, Der Bær, p 25.

${ }^{74}$ See e.g. Paula Perlman, 'Plato Laws 833C-834D and the Bears of Brauron' (1983) 24(2) Greek, Roman and Byzantine Studies 115-130. The age limits have been the subject of conjecture: see Ferrari, Figures of Speech, p 295 ( $n$ 26). Bachofen explains the ages of 5-10 as that which most closely corresponds with the idea of a mother's influence in shaping and forming her young. Bachofen, Der Bær, p. 24. Not having the benefit of analysing the krateriskeroi (which were uncovered between 1948-1963), Bachofen instead referred to two other artefacts which seemed to him to emphasize the principle of the arkteai in the comfort the bear gives to a mother or her child faced with the agonising survival after the death of a spouse. Bachofen, Der Bær, p 2728.

${ }^{75}$ Jean-Pierre Vernant and Francoise Frontisi-Ducroux, 'Features of the Mask in Ancient Greece' in Jean-Pierre Vernant and Pierre Vidal-Naquet, Myth and Tragedy in Ancient Greece, Trans. Janet Lloyd (Brooklyn: Zone Books, 1988), pp. 197-8. Cf Ferrari, who argues that the red-figure vase depicting the bear-human figures
} 
The reading of this myth that Vernant and Frontisi-Ducroux provide is to some extent reinforced by the myths of other peoples in which a dangerous relation to the bear emphasises problems to do with virginity and marriage, wildness and tameness for young women. ${ }^{76}$ As Laura Cherubini has recently construed in an analysis of these myths, 'bears remind people of the risks connected with the transformation from youth into adulthood - the dangers people can avoid if they conform to the behavioural rules of their community. ${ }^{, 77}$ Bachofen had also emphasized the maternal side of the arkteia, in which mothers had offered their daughters in tender childhood, hoping for 'protection, education, every happiness of youth and finally gamos. ${ }^{178}$

It is too difficult to know with any certainty why a bear-imitation by the girls of Athens can constitute reparation for the wounds occasioned by the 'tamed' wild animal, the killing of which, it seems, only sows greater strife for the city. We can speculate however that for young girls to 'play the bear' must have been thought of as an appeasing spectacle for the goddess of childbirth and mistress of wild animals, whose role as Vernant and Frontisi-Ducroux put it is to 'take charge of the offspring of human beings, who belong to her as do the offspring of animals ${ }^{79}$ and at the same time somehow a kind of penalty or expiation for the patriarchal people of Athens to have to observe for their daughters. This imitation, we can assume, is the price that has to be paid for a harm that seems to radically challenge the boundaries between the wild and the tame, human and animal, and the principles of accountability that attach thereto. Just as it must have been uncertain for these Athenians to know by what measure a person could be held responsible for the actions of a 'tamed' bear, the girls who - in imitating the bear - repeat the uncertainty over their own domestication, are also freed from the danger of really becoming the bear as well as from the risks associated with too

indicate that the myth of Callisto was central to the rite (see $\mathrm{fn}$... above). She provides a translation of the foundation myth from the Ravenna manuscript of Lysistrata as follows:

'A she-bear was given over to the sanctuary of Artemis and became tame. One day a girl teased her and was blinded by the bear. In his grief, the girl's brother killed the bear. Artemis then, enraged, demanded that every girl imitate (mimesasthai) the bear before she marry, and circle (periepein) the sanctuary wearing a saffron-colored mantle (krokoton himation), and this was called playing the bear (arkteuesthai). Others add that [Artemis] inflicted a plague upon the Athenians. And the goddess said that there would be an end to their woes, if as penalties for the slain bear they compelled their maidens to perform the bear (arkteuein). When the oracle was revealed, the Athenians decreed that a maiden could not marry, unless she had performed the bear for the goddess.' Ferrari, Figures of Speech, p 171. See also William Sale, 'The Temple Legends of the Arkteia' (1975) 118(3) Rheinisches Museum für Philologie 265-284.

${ }^{76}$ See especially Laura Cherubini, 'The Virgin, the Bear, the Upside-down Strix: An Interpretation of Antoninus Liberalis 21' (2009) 42(1) Arethusa 77, at 81-89.

${ }_{78}^{77}$ Cherubini, 'The Virgin, the Bear, the Upside-down Strix', p 88.

${ }^{78}$ Bachofen, Der Bær, p. 27.

${ }^{79}$ Vernant and Frontisi-Ducroux, 'Features of the Mask', p 197. 
closely imitating, not the bear but the goddess who, as virgin huntress, 'pursues and massacres the male she ought to marry'. ${ }^{80}$

Despite another interpretation of this rite that has recently deemphasised the presence and significance of the bear, ${ }^{81}$ from the juridical point of view we don't encounter the animal here in a neutral or ambiguous way. As the foundation myths seem to confirm - which from one perspective hold more than a superficial resemblance to the common law scienter scenarios we have already explored - the bear holds a meaning that is more certain than one for which any other wild animal would do. '[W] $\mathrm{W}$ ther we wish to privilege the interpretation of the arkteia as a mimesis of a shebear's taming or of its sexual development as a mother,' Cherubini writes, 'what we would apparently find at Brauron in the sign of the bear is the successful conclusion of a rite after which the girl is able to occupy her place as a woman in human society. ${ }^{182}$ It appears to bring with it a jurisprudence that imagines and dramatises the recompense for a harm occasioned by the bear in terms of a debt that cannot be made good through the ordinary means available to the city state which would barely be able to place a value on the animal - but at the level of a sacrifice for which only the Athenian girls in their relation to marriage and to the goddess Artemis can experience through an imitation of the animal.

\section{Bear-tracks in law: To be followed...}

Bachofen notes about the passage in Lysistrata, that we cannot so much complain if it is only through the form of its satirical derision that the memory of the Attic bear-rites has not completely vanished. ${ }^{83}$ One might say something similar of the juridical meaning of the bear which, in our attempt to follow its tracks more closely, we seem to encounter only through what the abstract form of positive law has subtracted from the picture. Nothing warrants us to bemoan the inadequacy of this legal literature when it presents the bear itself in a somewhat crude outline. Even in this inadequacy, the cold prudence of institutions, the sober attention to the procedural envelope, the care for the form and conduct of law that this literature preserves, gives us already a sensibility toward the animal the value of which is easy to overlook. If this animal has left distinct tracks for us

\footnotetext{
${ }^{80}$ Vernant and Frontisi-Ducroux, 'Features of the Mask', p 197.

${ }^{81}$ See Christopher A. Faraone, 'Playing the Bear and Fawn for Artemis: Female Initiation or Substitute Sacrifice' in David Brooks Dodd and Christopher A. Faraone (eds), Initiation in Ancient Greek Rituals and Narratives: New Critical Perspectives (London: Routledge, 2003), pp 43-68, who points to a similar set of rites that puts the fawn in the place of the bear and also questions the initiatory character of the arkteia.

${ }^{82}$ Cherubini, 'The Virgin, the Bear, the Upside-down Strix', p 88.

${ }^{83}$ Bachofen, Der Bær, p. 33.
} 
in the thought of law, as we have seen, it has done so as more than just a representation but also a kind of technical modification in jurisprudence: a modification that, whether we like it or not, does not leave the doctrinal terrain untouched. Without a way to read these tracks, how can anyone be blamed who, faced with a fork in the road, happens to follow the path that takes them close to the bear they would have rather avoided? 